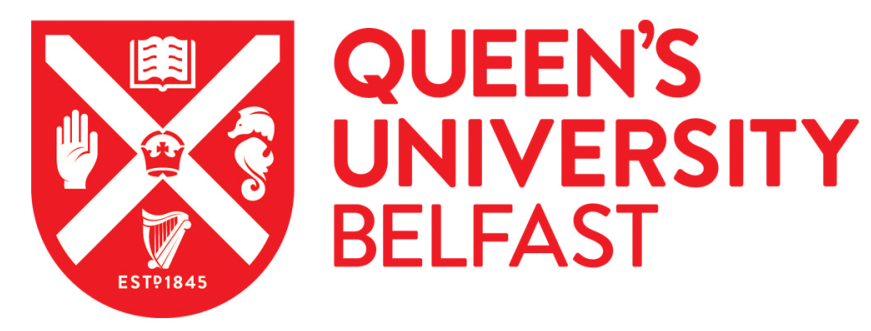

\title{
Geophysical and hydrogeological characterisation of the impacts of on-site wastewater treatment discharge to groundwater in a poorly productive bedrock acquifer
}

Donohue, S., McCarthy, V., Rafferty, P., Orr, A., \& Flynn, R. (2015). Geophysical and hydrogeological characterisation of the impacts of on-site wastewater treatment discharge to groundwater in a poorly productive bedrock acquifer. Science of the Total Environment, 523, 109-119.

https://doi.org/10.1016/j.scitotenv.2015.03.117

\section{Published in:}

Science of the Total Environment

\section{Document Version:}

Peer reviewed version

Queen's University Belfast - Research Portal:

Link to publication record in Queen's University Belfast Research Portal

\section{Publisher rights}

Copyright 2016 Elsevier B.V.

This manuscript version is made available under the CC-BY-NC-ND 4.0 license (http://creativecommons.org/licenses/by-nc-nd/4.0/), which permits distribution and reproduction for non-commercial purposes, provided the author and source are cited.

\section{General rights}

Copyright for the publications made accessible via the Queen's University Belfast Research Portal is retained by the author(s) and / or other copyright owners and it is a condition of accessing these publications that users recognise and abide by the legal requirements associated with these rights.

Take down policy

The Research Portal is Queen's institutional repository that provides access to Queen's research output. Every effort has been made to ensure that content in the Research Portal does not infringe any person's rights, or applicable UK laws. If you discover content in the

Research Portal that you believe breaches copyright or violates any law, please contact openaccess@qub.ac.uk. 


\title{
Geophysical and hydrogeological characterisation of the impacts of on-site wastewater treatment discharge to groundwater in a poorly productive bedrock aquifer
}

\author{
Shane Donohue ${ }^{\mathrm{a}}$, Valerie McCarthy ${ }^{\mathrm{b}}$, Patrick Rafferty ${ }^{\mathrm{b}}$, Alison Orr ${ }^{\mathrm{a}}$, Raymond Flynn ${ }^{\mathrm{a}^{*}}$ \\ a School of Planning, Architecture and Civil Engineering, Queen's University Belfast, David Keir Building, \\ Stranmillis Road, Belfast BT9 5AG, Northern Ireland. \\ b Department of Applied Sciences, Dundalk Institute of Technology, Dublin Road, Dundalk, Ireland.
}

\begin{abstract}
Contaminants discharging from on-site wastewater treatment systems (OSWTSs) can impact groundwater quality, threatening human health and surface water ecosystems. Risk of negative impacts becomes elevated in areas of extreme vulnerability with high water tables, where thin unsaturated intervals limit vadose zone attenuation. A combined geophysical/hydrogeological investigation into the effects of an OSWTS, located over a poorly productive aquifer (PPA) with thin subsoil cover, aimed to characterise effluent impacts on groundwater. Groundwater, sampled from piezometers down-gradient of the OSWTS percolation area, displayed spatially erratic yet temporally consistent contaminant distributions. Electrical resistivity tomography identified an area of gross groundwater contamination close to the percolation area and, when combined with seismic refraction and water quality data, indicated that infiltrating effluent reaching the water table discharged to a deeper more permeable zone of weathered shale resting on more competent bedrock. Subsurface structure, defined by geophysics, indicated that elevated chemical and microbiological contaminant levels encountered in groundwater samples collected from piezometers, down-gradient of sampling points with lower contaminant levels, corresponded to those locations where piezometers were screened close to the weathered shale/competent rock interface; those immediately up-gradient were too shallow to intercept this interval, and thus the more impacted zone of the contaminant plume. Intermittent occurrence of faecal indicator bacteria more than $100 \mathrm{~m}$ down gradient of the percolation area suggested relatively short travel times. Study findings highlight the utility of geophysics as part of multidisciplinary investigations for OSWTS contaminant plume characterisation, while also demonstrating the capacity of effluent discharging to PPAs to impact groundwater and water quality at distance. Comparable geophysical responses observed in similar settings across Ireland suggest the phenomena observed in this study are more widespread than previously suspected.
\end{abstract}

Keywords: Wastewater, Geophysics, Poorly productive aquifer, Groundwater quality, Coliforms 


\section{Introduction}

Residential on-site wastewater treatment systems (OSWTS), where wastewater discharges to the subsurface, act an important means of domestic wastewater disposal in many parts of the world where reticulated sewerage proves unavailable. This includes concentrated occurrence in urban areas in developed and developing countries (Hatt et al., 2004; Viraraghavan, T., 1976), and more diffuse occurrence in rural areas (Hoxley and Dudding, 1994; Withers, et al., 2011) In Ireland it is estimated that approximately one third of all private dwellings use these systems (CSO, 2012), particularly in rural areas where they constitute the principle technology employed for sewage treatment and wastewater disposal.

OSWTS can be broadly divided into two categories, septic tank systems and secondary treatment systems (e.g. mechanical aeration systems, filter systems, constructed wetlands). In both cases treatment of effluent should ideally render it innocuous with no significant impact on groundwater quality (Jenssen and Siegrist, 1990; van Cuyk et al., 2001). Processes operating in the vadose zone receiving OSWTS play a significant role in attenuating contaminants before they reach groundwater (van Cuyk et al. 2001). These include a variety of natural physical, chemical and biological processes, which remove microbiological and chemical pollutants (van Cuyk et al., 2001). The capacity of subsoil to appropriately receive and treat the wastewater, depends on its physical and geochemical properties of the receiving medium, including porosity, organic matter content, ion exchange capacity, unsaturated subsoil thickness separating effluent percolation areas from the water table, and permeability (Beal et al. 2005). Physical properties and loading rates influence the residence time of wastewater percolating through the vadose zone. Since the permeability $(K)$ of the soil varies with water content, wastewater flows more slowly through unsaturated subsoil, as described by the Richards Equation, thereby providing a greater opportunity for time-dependant chemical and biological processes to influence water quality. This, along with the availability of oxygen, enables decomposition and biodegradation of various contaminants (Canter and Knox, 1985). Conversely, the absence of a sufficiently thick vadose zone can result in reduced effluent attenuation capacity, elevating risk of contaminant delivery to human and surface water receptors.

In the Republic of Ireland, groundwater is classified as having "extreme vulnerability" if bedrock is located within $3 \mathrm{~m}$ of the surface (DELG/EPA/GSI 1999). It is estimated that $37 \%$ of land area of the Republic of Ireland falls within this category (Dr. Robert Meehan, Pers. comm), leaving groundwater at risk of contamination where OSWTS have been inappropriately sited in these areas. As Bales et al. (1995) demonstrated, the wider impacts of OSWTS effluent on groundwater will depend on contaminant migration rates, which in turn are a function of the geological and hydrogeological properties of aquifers. 
Although they are generally not considered to be important sources of water supply, poorly productive aquifers (PPAs) are believed to be important for baseflow and nutrient delivery to surface water receptors via shallower groundwater pathways, notably through relatively permeable transitional basal subsoil units and adjacent weathered bedrock (Moe et al. 2010). In Ireland, PPAs immediately underlie over $65 \%$ of the total land area (Comte et al., 2012). These often occur in extreme vulnerability settings. Despite their widespread occurrence, hydrogeological processes operating in PPAs, including contaminant transport and attenuation, remain poorly understood, largely as a consequence of a lack of studies arising from their perceived low productivity as groundwater supplies. However, promulgation of the EU Water Framework Directive requires member states to develop an integrated view of water resources and pressures threatening groundwater and surface water quality in catchments; this includes assessing the impacts of OSWTS on groundwater quality in PPAs (European Commission, 2000).

Ordovician and Silurian lithified sandstone (greywacke) and shale units are considered as PPAs (Moe et al., 2010). Despite their wide distribution across Europe (UK, Ireland, Scandinavia) (Mc Kerrow, 1981; Andersson, 1985) and Eastern North America (Sloss ,1963) and their local use as domestic water supplies, their role as units facilitating groundwater flow in the near surface remains poorly defined (Robbins, 2002), Comparable shale and greywacke deposits occur widely elsewhere around the globe. The presence of pyrite, organic matter and carbonate, particularly in shales, can make these units susceptible to chemical weathering (Littke et al. 1991), while at the same time these substances, and associated chemical weathering by products, such as iron oxides, can influence contaminant fate and transport in groundwater systems (Tesoriero et al., 2000, Ryan et al., 1999). The effects of chemical weathering are considerably less pronounced in more recently glaciated terrains, where physical weathering dominates (Summerfield, 1991). The impact of these conditions on contaminant mobility in shale and greywacke groundwater systems in Northern Europe remains poorly characterised despite the presence of widespread pressures that may affect water quality.

Characterising hydrogeological processes operating in PPAs can prove challenging. Geological conditions are often poorly defined compared to more productive aquifers, despite significant progress in this area in recent years (Nitsche 2014, Moe et al. 2010, Comte et al., 2012). On the other hand an understanding of the configuration and distribution of hydrogeological properties in the subsurface forms the cornerstone of realistic conceptual model development. Studies on PPAs, completed to date, show that although they can have highly heterogeneous subsurface configurations, their geometry can be better constrained by geophysics (Comte et al. 2012, Cassidy et al, 2014). These configurations in turn can influence contaminant transport rates and, depending on conditions encountered along flow paths, also affect attenuation processes. 
Geophysical methods have been used by a number of authors for detecting, characterising and monitoring contaminants derived from domestic and/or industrial waste storage/disposal facilities (landfills). Electrical and electromagnetic methods often prove useful for detection of ionic contaminants that increase pore fluid conductivity (thereby reducing the bulk resistivity). Applications of these techniques for detecting and monitoring contaminant plumes and for predicting future contaminant pathways have been described by many authors (e.g. Aristodemou and Thomas-Betts 2000; Buselli and Lu 2001; Martinho and Almeida 2006; Santos et al. 2006; Lee et al. 2006; Perozzi and Holliger 2008, Casado et al. 2015). A number of authors have also demonstrated reasonable correlations between apparent electrical resistivity / conductivity $\left(\mathrm{EC}_{\mathrm{a}}\right)$ and concentrations of various chemicals in groundwater, including those that may contain microbiological contaminants. For example, $\mathrm{EC}_{\mathrm{a}}$ has been correlated with concentrations of $\mathrm{K}^{+}, \mathrm{Na}^{+}, \mathrm{Cl}^{-}, \mathrm{SO}_{4}{ }^{2-}, \mathrm{NH}_{4}{ }^{+}$, and $\mathrm{NO}_{3}{ }^{-}$in soils affected by animal manure wastes (Eigenberg et al., 1998; Martínez-Pagán et al. 2009; Ranjan and Karthigesu, 1995; Stevens et al., 1995). By contrast, more limited research has been published on the use of geophysics for assessing contaminants resulting from wastewater treatment systems (e.g. Lee et al. 2006; Donohue et al. 2010).

By utilising a combined geophysical/hydrogeological approach, this study aimed to investigate the impact of OSWTS effluent on groundwater quality in a poorly productive shale and greywacke aquifer with a shallow water table. Selection of a subset of a suite of water quality parameters focusing on (a) a non-reactive chemical constituent (Chloride) and (b) microbiological parameters, whose concentrations depend on residence time in groundwater systems, provided a basis for refining a conceptual model of the physical hydrogeology of the system by integrating findings with water level, hydraulic conductivity and geophysical data.

\section{Methodology}

\subsection{Site description}

The Drumaliss Test Site is located within the Lough Muckno Catchment, Co. Monaghan, Ireland (Figure 1). An abstraction point draws water from the lake to provide three towns with potable water. Owing to community concern regarding the deterioration of the raw water quality, the Lough Muckno catchment has been the subject of an intensive water quality monitoring programme. A catchmentwide survey identified the principal water quality pressures as poor farmyard practices, cattle access to streams and runoff from slurry and synthetic fertiliser spreading (McCarthy et al. 2010). However, the impact of other types of contamination on water quality within the poorly drained sub-catchment containing the test site has warranted more detailed investigation of domestic wastewater delivery 
mechanisms to surface water bodies. Based on these observations, a site-specific environmental monitoring programme aimed to assess the impact of OSWTS effluent on water quality through a two year programme of hydrological, hydrogeological and water quality monitoring at sites across the Lough Muckno Catchment in a range of physical settings.

The Drumaliss Test Site occurs on the south-eastern shoulder of a low ridge, within a hummocky area of drumlin landscape adjacent to a residence housing five adults. The site slopes to the south east with a gradient ranging between $<1 \%$ and $6 \%$. A shallow stream flows from north to south approximately $125 \mathrm{~m}$ south-southeast of the house's OSWTS and flows into Lough Muckno $460 \mathrm{~m}$ south-southwest of the site. The OSWTS and associated percolation area are located in the garden immediately northeast of the house (Figure 2). The site is located in an area reported to be covered by thin glacial subsoils, resting on a poorly productive sequence of highly compacted Lower Palaeozoic greywackes and shales. According to $19^{\text {th }}$ century field survey geological maps, the Drumaliss site is located on the sedimentary contact between these rock types (Figure 1), which dips to the northwest at an angle of approximately 40 degrees. The older shale unit (Moffat Shale) lies to the south of the OSWTS and is described as in outcrop dark and fissile. Local superficial geological maps record the overlying subsoil for both shale and greywacke as having 'low' permeability, suggesting limited infiltration capacity (Geological Survey of Ireland, 2014).

The map of the site in Figure 2 presents the locations of the groundwater monitoring network installed to characterise the impacts of OSWTS effluent on groundwater quality. A trial pit excavated at the site, close to the shale/greywacke contact, revealed a $10-15 \mathrm{~cm}$ thick A horizon of loam overlying a $30-50 \mathrm{~cm}$ thick B horizon/subsoil layer (sandy silt with common gravels). Fractured, weathered rock $(0.7-0.9 \mathrm{~m}$ thick) was observed separating the subsoil from underlying competent bedrock (McCarthy et al., 2010).

\subsection{Geophysical Investigation}

Geophysical surveys of the Drumaliss Test Site aimed to (a) evaluate the capacity of Electrical Resistivity Tomography (ERT) for delineating the extent of OSWTS effluent-impacted groundwater, and (b) use ERT, in conjunction with seismic refraction, to characterise the geometry of subsurface deposits below the site to identify the location of possible contaminant pathways.

Surveys were completed at the start of July 2010 during a period of warm ( 20Deg C) dry weather, when groundwater levels were lower than average levels measured in monitoring wells during previous monitoring in 2008-2009. Galvanically coupled ERT measurements were acquired along a number of transects around the site (Figure 2) using two different resistivity meters, a Campus Tigre (Allied Associates, Dunstable, UK) and a SyscalPro (Iris Instruments, Orléans, France). 
The SyscalPro was used for acquiring short, high resolution profiles in the vicinity of the OSWTS (electrode spacing $\leq 1 \mathrm{~m}$ ), whereas the Tigre was used for all other profiles. All ERT profiles acquired are listed on Table 1, along with the relevant data acquisition parameters. Electrodes were spatially referenced using a Trimble PRO-XR dGPS. Background resistivity was measured along Profile R11, which was located up-gradient of the OSWTS to evaluate the impact of effluent on ERT responses (Figure 2). Inversion of all of the apparent resistivity data was carried out with the software Res2Dinv (Loke 2004) using the $L_{1}$ norm inversion optimisation method. Due to the large contrast in subsurface resistivity present at the site, the quasi-Newton least squares method (Loke and Barker 1996) was not deemed appropriate. Instead the Gauss-Newton method (Sasaki, 1989; deGroot-Hedlin and Constable 1990) was selected for the first 3 iterations, after which the quasi-Newton method was used. In many cases, this provides the best compromise between computational time and accuracy even at sites with large resistivity contrasts (Loke and Dahlin 2002). For this study the majority of inversions performed converged to a normalised root-mean-squared (RMS) error of less than $6 \%$ within 5 or 6 iterations.

Seismic refraction data were recorded using a Geometrics Geode seismograph. A $10 \mathrm{~kg}$ sledgehammer was used to generate the seismic waves which were in turn detected by $10 \mathrm{~Hz}$ vertical geophones. Acquisition parameters are reported in Table 2. The majority of profiles were acquired using 24 geophones at a spacing of $2 \mathrm{~m}$, although this was altered on a number of occasions to take into account site specific limitations. In general for seismic refraction testing, shots (hammer blows) were recorded at every sixth geophone, with offshots recorded off each end of the profile. As with the ERT data, geophones were spatially referenced using a Trimble PRO-XR dGPS. In most cases, clear and unambiguous first arrivals were observed on the acquired profiles. The refraction data were interpreted using GREMIX, which incorporates the slope-intercept method, parts of the Plus-Minus Method of Hagedoorn (1959), Time-Delay Method (see Wyrobek 1956), and features the Generalized Reciprocal Method (GRM) of Palmer (1980).

\subsection{Hydrology and Hydrogeology}

The Drumaliss Test Site experiences a cool humid climate. Annual effective rainfall in the area is reported at approximately $640 \mathrm{~mm} /$ year, of which up to $100 \mathrm{~mm}$ becomes groundwater recharge by direct infiltration (Geological Survey of Ireland 2014). Prior to initiation of investigations at the site, no groundwater level data were available for the area. However, analogies with other investigations completed by Moe et al, (2010) in comparable poorly productive units suggested that groundwater levels reflected a subdued version of topography, with groundwater flowing discharging predominantly to the nearest downslope surface water body via an interval between the bedrock and

Page $\mid 6$ 
overburden. Hydraulic conductivity values in this interval typically exceed those of the enveloping units, but are also prone to display higher levels of heterogeneity (Moe et al. 2010).

Due to logistical constraints on monitoring well locations, five 1.5" $(32 \mathrm{~mm})$ internal diameter HDPE piezometers with $1 \mathrm{~m}$ or $2 \mathrm{~m}$ long slotted screened intervals at their base were installed in a line adjacent to a field boundary, extending from immediately down-slope of the OSWTS percolation area for approximately $120 \mathrm{~m}$ to close to the northern bank of the adjacent stream at the south-eastern end of the site A further monitoring well, installed outside the anticipated area of the OSWTS plume, aimed to permit determination of background concentrations of target contaminants. The monitoring wells permitted routine water quality and groundwater level monitoring. Ground clearance of fencing and light structures prior to building works in the field immediately to the south of the percolation permitted the temporary installation of a further three plastic piezometers and five stainless steel drive points, all with $1 \mathrm{~m}$ long screened intervals at their base, immediately prior to construction, and shortly after the completion of geophysical surveys in July 2010. These points provided improved characterisation of hydraulic gradient across the site, following stabilisation of groundwater levels.

Routine (approximately fortnightly) manual static water level readings, collected immediately prior to water quality sampling/monitoring, provided an indication of the range of groundwater level fluctuation encountered in both space and time across the site. Measurements completed in July 2010, were levels in all piezometers were noted, were carried out during a warm ( 20Deg C) period with no rainfall measured at the nearby meteorological station (Ballyhaise, Co. Monaghan) during the preceding five days. Rising head tests aimed to quantify the hydraulic conductivity of the deposits underlying the site. Test data, collected from five of the six permanent piezometers were analysed by the Bower and Rice (1976) method to account for partial penetration of screened wells in unconfined aquifers (Butler et al. 1996; Fetter 2001).

The infiltration capacities of shallower deposits were determined using a modified version of the on-site falling head percolation test (the ' $T$-test'). This test provides a 'T-value' which equated to the average time in minutes it takes for the water level to fall $25 \mathrm{~mm}$ in each of two percolation test holes dug at depths to at least $400 \mathrm{~mm}$ below ground level. A low 'T-value' $(<3)$ denotes a coarse grained soil that is highly permeable in nature and is, therefore, not suitable for the installation of a septic tank, while a high 'T-value' $(>50)$ is more indicative of a less permeable, often clayey soil, which is again not suitable for a conventional septic tank. The percolation test at the site involved the excavation of two percolation test holes which were dug in an area adjacent to the current percolation area, details of which can be found in McCarthy et al (2010). 


\subsection{Water Quality}

Where a sufficiently deep column of water was present, in-situ specific electrical conductance (SEC), $\mathrm{pH}$ and groundwater temperature were measured in the five groundwater monitoring wells down gradient of the OSWTS percolation area approximately every two weeks between August 2008 and June 2009 during water quality sampling. Samples were collected using a low flow peristaltic pump to minimise particle mobilisation and alteration of the physical properties of the deposits in the immediate vicinity of well screens. Laboratory based analyses of these samples were carried out in order to provide data on the concentration of chloride, a non-reactive chemical parameter, and microbiological parameters. Analysis of samples for chloride was carried out by Ion Chromatography using a Dionex ${ }^{\circledR}$ ICS-2000 system, while analysis of the faecal indicator microorganisms (FIOs), Total coliforms and Escherichia coli (E.coli) were performed by the most probable number (MPN) method using Quanti-tray 2000® (Idexx Laboratories, Inc., Westbrook, Marine, USA). All samples destined for microbiological analysis were chilled immediately upon sampling and analysed within 24 hours of sample collection. Samples for chloride analyses were frozen if an immediate analysis was not possible.

\section{Results}

\subsection{Interpretation of Geophysical Data}

Six of the two-dimensional inverted ERT profiles were combined into a quasi-three-dimensional fence diagram in Figure 3, in order to reflect the 3D distribution of resistivity below the site. Four inverted high resolution ERT profiles located close to the treatment system are presented separately in Figure 4 for clarity. Interpreted seismic refraction layered models for profiles S2, S3, S4 and S5 are overlain on the relevant 2D ERT profiles in Figures 4 and 5 for comparison and joint interpretation.

The profiles suggest that the effluent plume originating from the OSWTS occurs as a zone of lower resistivity relative to the surrounding material in the vicinity of the percolation area (Figure 3 and Figure 4), with the resistivity values measured in this area (20-110 $\Omega \mathrm{m})$ being significantly less than the equivalent background level measured in Profile R11 $(>300 \Omega \mathrm{m})$. It is estimated that the effluent is represented by a zone of relatively low resistivity, up to $14 \mathrm{~m}$ wide and $1.5 \mathrm{~m}$ thick, with the majority of the effluent occurring between approximately $0.5 \mathrm{~m}$ below ground surface(mBGS) and $1.7 \mathrm{mBGS}$ (Figure 4).

Three layers were detected in all seismic refraction profiles (Figures 4 and 5). The soil / subsoil layer boundary observed in trial pits during the initial site investigation was too shallow to detect with the seismic refraction geometry used. The shallowest layer (Layer 1) detected by seismics 
represents the base of the subsoil at between 0.75mBGS $-1.2 \mathrm{mBGS}$ with a P-wave velocity of between $180 \mathrm{~m} / \mathrm{s}$ and $400 \mathrm{~m} / \mathrm{s}$. The main body of the effluent plume appears to travel in the lower part this layer, which extends down gradient for up to $25 \mathrm{~m}$ from the end of the percolation area (Figure 5, inset). Beyond this distance, the data generated by ERT can no longer confidently identify the plume.

The thickness of the layer underlying the subsoil varies between $1 \mathrm{~m}$ and $3 \mathrm{~m}$. The P-wave velocity of this layer (Layer 2) varies between $450 \mathrm{~m} / \mathrm{s}$ and $950 \mathrm{~m} / \mathrm{s}$. This layer appears to be thicker in the central portion of the site, and, for the most part appears to correspond to a zone of high resistivity, observed on the ERT profiles to a depth of around 3mBGS to 4mBGS (Figure 5). Joint interpretation of the ERT and seismic refraction data, coupled with trial pit observations, suggest that this material corresponds to fractured and weathered shale. Although there is no clear evidence from the ERT profiles to indicate wastewater effluent travelling through this layer, it represents a potential pathway for wastewater, possibly along the interface with the underlying competent bedrock, where weathered shale hydraulic conductivities appear higher (See below). The absence of a definitive geophysical signal related to the effluent plume may be attributable to the low resistivity of the underlying competent bedrock (Layer 3), which is likely to have masked any resistivity reduction resulting from wastewater effluent within this zone. Interestingly, the inverted resistivity in the vicinity of piezometer D9, between OmBGS and 2 mBGS, is again low relative to the surrounding material.

Although the P-wave velocities of Layer 1 and Layer 2 do not vary consistently across the site, the velocity of Layer 3 is considerably higher in the Northwest $(4000 \mathrm{~m} / \mathrm{s})$, indicating competent greywacke bedrock, compared to the shale velocities to the SE which vary between $2200-2500 \mathrm{~m} / \mathrm{s}$ (Figure 5). The resistivity of Layer 3 also varies considerably from NW to SE and clearly indicates the location of a geological contact (at a profile distance of $\sim 80 \mathrm{~m}$ ). The lower resistivity/ low velocity values measured in the central and SE part of the site are typical of shale, whereas the high resistivity/ high velocity values measured in the NW reflect the steeply dipping greywacke, as indicated at outcrops on the geological map of the region. The seismic refraction and resistivity data have confirmed that the bedrock is, for the most part, within $3 \mathrm{~m}$ of the surface and the site should therefore be considered to have 'extreme' groundwater vulnerability (DELG/EPA/GSI 1999).

\subsection{Hydrogeology}

Water level monitoring data, summarised in Table 3 indicates that groundwater occurs near the ground surface close to the OSWTS but declines moving down-gradient to the Southeast; levels in the closest of these piezometers, D4 were above the base of the percolation area $150 \mathrm{~cm}$ below ground surface)The depth to groundwater and the range of groundwater fluctuation increase to the southeast, where water level monitoring indicates groundwater to occur between 1.8mBGS and 
2.65mBGS, while water levels in piezometer D9, closest to the river, range between 0.42mBGS and 0.68mBGS. Compilation of water level data from monitoring wells, in conjunction with those observed in temporary piezometers has permitted generation of a piezometric surface map (for July 2010) for the site (Figure 6) and indicates that groundwater flows from the percolation area to the south east along the line of permanent monitoring wells with a relatively uniform gradient of approximately $5 \%$.

A T-value of $38 \mathrm{~min} / 25 \mathrm{~cm}(\mathrm{n}=2)$ was measured in the trial pit, which would typically indicate reasonable subsoil percolation capacity and suggest that the site is suitable to receive OSWTS effluent.

Table 4 summarises the results of the falling head tests carried out on selected piezometers. Test results, analysed using the Aqtessolv 3.0 (Hydrosolv, Inc.) suggest that hydraulic conductivity in the deposits adjacent to piezometer screens ranges between $10^{-6} \mathrm{~cm} / \mathrm{sec}$ and $10^{-3} \mathrm{~cm} / \mathrm{sec}$. Both highest and lowest values were observed in piezometers screened at the levels corresponding to the base of the weathered shale layer, as identified by geophysical data interpretation. By contrast hydraulic conductivities vary less in the adjacent overlying deposits. The higher levels of heterogeneity encountered in the basal unit are consistent with observations made at other Irish PPA test sites, although hydraulic conductivities are generally considered to be greater at depth (Moe et al. 2010). By analogy, the high $\mathrm{K}$ value determined from the test in $\mathrm{D} 9$ is suspected to broadly reflect the hydraulic properties of the basal section of the of the weathered bedrock unit, as observed elsewhere (Moe et al., 2010). A preliminary 2D numerical model suggests that this condition would encourage downward groundwater flow across most of the site. By contrast, the lower hydraulic conductivity observed in D7 is suspected to reflect locally tight conditions (i.e. lower density of hydraulically active fractures).

\subsection{Water Quality}

Table 3 summarises SEC, $\mathrm{Cl}^{-}$, total coliforms and E.coli concentrations in the piezometers down gradient of the OSWTS. Although consistent seasonal variations in water quality and groundwater level were not apparent from routine monitoring, persistently high values of both SEC and $\mathrm{Cl}^{-}$were recorded in monitoring well D4, nearest to the treatment system (22m southeast) and adjacent to the percolation area. Samples taken from the other monitoring wells at the site, which were located up to $102 \mathrm{~m}$ from the system revealed significantly lower concentrations due to effluent mixing, with waters having lower SEC and $\mathrm{Cl}^{-}$values. Figure 6 presents median SEC values encountered at each of the monitoring wells. A comparable trend occurs with total coliform concentrations which proved high close to the percolation area (D4) but declined moving down-gradient, while also displaying greater variation relative to median concentrations.

Page | 10 
Overall contaminants displayed a trend where concentrations declined with distance from the percolation area. However, the pattern proved irregular. Concentrations in groundwater samples collected from monitoring wells D7 and D9 were always higher than piezometers immediately upgradient to the northwest, at D6 and D8 (Table 3 and Figure 6)

\section{Discussion}

Figure 7 presents a schematic illustration of contaminant migration below the Drumaliss Test Site that aims to integrate the geophysical, hydrogeological and water quality data collected. The results of the geophysical surveys demonstrated that the method provided a means of mapping gross OSWTSimpacts to groundwater quality up to $25 \mathrm{~m}$ down gradient of the percolation area. Beyond this distance, the data generated by ERT can no longer confidently define the plume. This is consistent with the declining general trend observed in $\mathrm{Cl}^{-}$and SEC values, where lower contaminant concentrations were detected in groundwater samples collected from more distal monitoring wells. ERT, when combined with seismic data has also proven a valuable tool for defining the configuration of the different lithologies overlying competent bedrock (and therefore the potential contaminant pathways), as well as the gross structure in the competent bedrock. Both the resistivity levels and seismic velocities determined compare favourably with those observed for Lower Palaeozoic shales and greywackes encountered elsewhere in Ireland (O'Connor et al., In Preparation). The low electrical resistivities in the competent shale bedrock are believed to reflect the high graphite and pyrite levels; elevated concentrations of the minerals occur widely in unweathered Moffat shales (Beamish et al. 2010; Rogers et al. 2015.)

The high water table in the immediate vicinity of the percolation area indicates that little to no chemical and biological vadose zone attenuation of contaminants can occur. This is further compounded by the fine grained nature of the subsoil, leading to a suspected significant thickness of capillary fringe with subsoil permeability approaching maximum (saturated) levels according to the Richards Equation. Moreover, since the groundwater levels measured at D4 correspond to depths equivalent to the base of the percolation area, this would suggest that the vadose zone plays a negligible role in contaminant attenuation in this setting. High groundwater levels are believed to have contributed to gross impacts to groundwater quality in the subsoil that extend down gradient, as reflected by the elevated $\mathrm{Cl}^{-}$and $\mathrm{FIO}$ concentrations observed in piezometer D4. Geophysical data suggest that the change in depth to groundwater moving down gradient corresponds to an increase in the thickness of weathered shale and to a decline in the elevation of its interface with competent bedrock. This is suspected to increase the transmissivity of the weathered shale, contributing to the decline in groundwater level observed down gradient of the percolation area.

Page | 11 
Although effluent-derived contaminant concentrations in groundwater decline notably moving down gradient, they prove spatially erratic, yet temporally consistent. These variations deviate significantly from those anticipated under uniform conditions where concentrations would decline regularly moving away from a contaminant source. Consideration of variations in subsurface geological conditions with depth assists in reconciling anomalies observed, i.e. concentrations are not uniform with depth at the points sampled. Those wells containing elevated contaminant concentrations, relative to monitoring points immediately up gradient (e.g. D7 and D9) have screened intervals set towards the base of the weathered shale contact with competent bedrock, as identified by geophysics (Figure 7). By contrast associated those immediately up-gradient (with lower concentrations) have screened intervals set higher above the contact and fail to intersect the more contaminated part of the plume (i.e. D6, D8).

The elevated contaminant concentrations encountered in groundwater samples collected from the contact between the weathered shale and competent bedrock units suggest that OSWTS effluent has descended through the weathered shale and migrates preferentially at depth. The absence of monitoring points in the underlying competent rock prevents characterisation of contaminant migration at greater depth. However, seismic and geoelectrical data suggest that the competent rock is relatively tight and unweathered; this would imply it has a lower hydraulic conductivity that leads to contaminant migration occurring predominantly at the base of the more permeable overlying unit.

Overall reductions of contaminant concentrations with distance from the percolation area arise in part due to dilution, as reflected by reduced $\mathrm{Cl}^{-}$in water samples collected in piezometers down gradient of D4 (located beside the percolation area). However, after accounting for background concentrations of approximately $12 \mathrm{mg} / \mathrm{l}$, determined from lowest concentration quartile values at piezometers D4, D6 and D8 and comparison with rainfall content, the degree of dilution appears low. Monitoring well data suggest that effluent flowing between the most highly contaminated monitoring point, immediately down gradient of the infiltration area (D4), and the most distal monitoring point (D9) has experienced dilution with uncontaminated groundwater by a factor of around three. By contrast median total coliforms data indicate that they have experienced attenuation by a factor of more than 25. The disproportionate reduction in levels of microbiological contaminants points to additional reactions that give rise to supplemental attenuation, such as filtration and microbiological inactivation (Foppen and Schijven, 2006). These reactions add a further degree of protection against the impacts of effluent on water supplies destined for human consumption. However, sporadic detection of elevated concentrations of E.coli, encountered in over $25 \%$ of samples collected from D9, yet absent in groundwater collected from background wells, indicates that effluent can influence the microbiological quality of the site's groundwater even at relatively prolonged distances $(100 \mathrm{~m}+)$.

Page $\mid 12$ 
The occurrence of FIOs in monitoring wells over $100 \mathrm{~m}$ from the percolation area, in conjunction with elevated chloride concentrations (see Table 4), suggests that a portion of the effluent discharging to groundwater can reach monitoring wells in relatively short periods of time, while experiencing limited dilution with unimpacted water. These findings appear to conflict with relatively low hydraulic conductivity values measured at the site (Geometric mean $=8.75 \times 10^{-5} \mathrm{~cm} / \mathrm{s}$ ) and hydraulic gradients of the order of 0.05 , that suggest site groundwater has a specific flux of around $4 \times 10^{-3} \mathrm{~m} / \mathrm{d}$. However, findings can be reconciled by considering the properties of hydraulically active flow paths in the host materials, i.e. in the effective porosity. Visual observations of the weathered shale noted few fractures in an otherwise massive clay matrix. These observations, evidence for rapid travel times, and limited mixing of effluent with uncontaminated water, suggest a restricted number of groundwater flow paths, some of which allow effluent-impacted groundwater to flow rapidly through them. This is consistent with a low porosity medium, in which groundwater having elevated SEC would contribute little to the change in a medium's bulk resistivity, as observed in the resistivity transects extending away from the percolation area. Overall study findings demonstrate that contaminants in the site's OSWTS effluent, capable of impacting human health, can migrate significant distances through poorly productive aquifers.

\section{Conclusions}

Effective treatment of effluent generated by on-site wastewater treatment systems (OSWTS) is essential for the protection of groundwater and surface water quality. This combined geophysical/hydrogeological investigation, carried out to assess of the impact of e an OSWTS located over a thin layer of glacial till subsoil resting on a poorly productive greywacke/shale bedrock aquifer, has demonstrated that microbiologically contaminated effluent has the capacity to cause gross contamination of groundwater in the immediate vicinity of the percolation area. At the Drumaliss Test Site this occurred in a hydrogeological setting where the role of attenuation in the vadose zone proved negligible. The multidisciplinary approach adopted in this study provided a means for investigating impacts of OSWTS effluent to groundwater both close to the percolation and at distance.

Geophysical methods have acted as important tools in both characterising the extent of gross groundwater contamination and the subsurface geometry of the receiving units in this study. These data, coupled with the hydrogeological measurements, and the results of water quality analyses demonstrate the need to consider how geological setting can influence the water level and water quality monitoring data that are necessary for the development of conceptual models of contaminant behaviour. On the other hand, failure to properly consider geological setting may lead to inappropriate monitoring well siting, which could generate data that contribute to incorrect interpretations of 
contaminant fate and transport; this could include over-estimating attenuation rates if monitoring wells fail to intercept the main body of a plume. Similarly, failure to install monitoring wells in the immediate vicinity of the percolation area, but instead to monitor with wells located further down gradient, would have suggested that a significant thickness of vadose zone exists that could assist in contaminant degradation.

The geophysical techniques adopted in this study assisted in developing an improved site conceptual model that permitted the significance of groundwater quality data to be appreciated in a realistic hydrogeological framework. Overall, the current study demonstrates that, despite the extreme vulnerability setting and the capacity of OSWTS effluent to cause localised gross groundwater pollution, contaminant attenuation can occur along the groundwater pathway connecting the test site percolation area to down-gradient receptors, despite the absence of a significant vadose zone in the vicinity of the percolation area. However, dilution rates have proven low. This is suspected to be due in part to low effective porosity of the weathered shale, as reflected by limited mixing of non-reactive constituents in the effluent with unimpacted groundwater. Biological and chemical processes provide additional mechanisms for reducing the concentration of reactive contaminants, such as FIOs. However, in cases where the water table approaches the ground surface its influence on attenuation processes can prove negligible. Nonetheless, reactive attenuation does occur, but this has proven to be limited. The detection of FIOs in monitoring wells over 100m down gradient of the percolation area demonstrates the capacity of effluent to impact the microbiological quality of PPA groundwater at considerable distances from their source. These findings suggest that OSWTS effluent entering PPAs can have detrimental impacts to groundwater quality over greater distances than previously anticipated in this type of setting and may also affect the quality of nearby surface water, particularly during periods when baseflow dominates and groundwater contributions to discharge are proportionally higher. In the absence of further attenuation, this contributes to human health risks, particularly where OSWTS are located closer to surface water receptors that act as potable water supplies.

The contributions made by seismic profiling and ERT in this investigation demonstrate the value of geophysics as an integral element of a site characterisation programme aimed at improving understanding of the impacts of OSWTS pollution on groundwater and surface water quality in areas underlain by poorly productive aquifers. Observations of comparable geophysical characteristics in Lower Palaeozoic shales elsewhere in Ireland suggest that the deposits investigated in this study are widespread. This is corroborated by observations made by soil scientists working in areas underlain by Ordovician and Silurian shales across the northern part of Ireland, covered by Drumlins, who noted that weathered shale forms the standard overburden material over intact shale bedrock 
(M.Breathnach, Soil Survey of Ireland (Ret.), pers comm). Consequently the phenomena observed in this study are suspected to be more widespread than previously anticipated.

\section{Acknowledgements}

For this work, the first author was funded by the Environmental Protection Agency (Ireland), under the Science, Technology, Research and Innovation for the Environment (STRIVE) fellowship programme (2008-FS-S-5-S5). Dr. Valerie McCarthy was funded by the Western River Basin District, ESB International and the Department of the Environment, Heritage and Local Government. Dr. Raymond Flynn and Dr. Alison Orr's activities were facilitated by the EPA STRIVE Programme "Assessing, modelling and managing water and contaminant movement along pathways (underground and overground) from the land surface to aquatic receptors, including the roles of contaminant transport and attenuation." (2007-WQ-CD-1-S1).. Dr. Flynn wishes to acknowledge further support provided in this investigation through the Griffith Geoscience research programme. This work is based on a research grant aided by the Irish Department of Communications, Energy and Natural Resources under the National Geoscience Programme 2007-2013. The views expressed are the author's own and do not necessarily reflect the views and opinions of the Minister for Communications, Energy and Natural Resources. The authors would like to thank the National Federation of Group Water Schemes, the homeowners and members of the Churchill and Oram Group Water Scheme for providing access to this site.

\section{References}

Andersson, A. (1985). The Scandinavian alum shales (No. 56). Sveriges geologiska undersökning.

Aristodemou, E. and Thomas-Betts, A. (2000). DC resistivity and induced polarisation investigations at a waste disposal site and its environments, Journal of Applied Geophysics, 44, 275-302.

Bales, R.C., Shimin, L., Maguire, K.M., Yahya, M.T., Gerba, C.P., Harvey, R.W. (1995) Virus and bacteria transport in a sandy aquifer, Cape Cod, MA. Groundwater 33: 653-661

Beal, C.D., Gardner, E.A., Menzies, N.W. (2005) Process, performance and pollution potential: A review of septic tank-soil adsorption systems. Soil Research 43(7) 781-802.

Beamish, D., Kimbell, G. S., Stone, P., \& Anderson, T. B. (2010). Regional conductivity data used to reassess Early Palaeozoic structure in the Northern Ireland sector of the Southern Uplands-DownLongford terrane. Journal of the Geological Society, 167(4), 649-657.

Bower, H., and Rice, R.C. (1976) A slug test for determining hydraulic conductivity of unconfined aquifers with completely or partially penetrating wells. Water Resources Research 12: 423-428.

Butler, J.Jr, McElweesee, C.D., Liu, W. (1996) Improving the quality of parameter estimates obtained from slug tests. Ground Water 34, No. 3, 480-490.

Buselli, G., and Lu, K. (2001). Groundwater contamination monitoring with multichannel electrical and electromagnetics methods, Journal of Applied Geophysics, 48, 11-23.

Canter, L. and Knox, R. (1985). Septic Tank System Effects on Groundwater Quality. Lewis Publishers, Chelsea, MI, USA.

Casado, I. Mahjoub, H., Lovero, R., Fernández, J. and Casas, A. (2015). Use of electrical tomography methods to determinate the extension and main migration routes of uncontrolled landfill leachates in fractured areas. Science of the Total Environment; 506-507:546-553

Cassidy, R., Comte, J.C., Nitsche, J., Wilson, C., Flynn, R., Ofterdinger, U. (2014) Combining multiscale geophysical techniques for robust hydro-structural characterisation in catchments underlain by hard rock in post-glacial regions. Journal of Hydrology, Vol. 517, p. 715-731.

Page $\mid 15$ 
Comte, J.C., Cassidy, R., Nitsche, J., Ofterdinger, U., Pilatova, K., Flynn, R. (2012) The typology of Irish hard rock aquifers based on an integrated hydrogeological and geophysical approach.Hydrogeology Journal, Vol. 20, No. 8, , p. 1569-1588.

CSO, (2012). Central Statistics Office ,Profile 4: The Roof over our Heads. Stationary Office, Dublin, Ireland.

DELG/EPA/GSI (1999) Groundwater Protection Schemes. Department of the Environment and Local Government, Environmental Protection Agency and Geological Survey of Ireland, 24 pp.

Donohue, S., Flynn, R., McCarthy, V., Orr, A., Rafferty, P. and Galvin, K. (2010) Geophysical assessment of contamination from a wastewater treatment system in the Milltown lake catchment, Ireland. EAGE Near Surface 2010, 16th Annual Meeting of Environmental and Engineering Geophysics, Zurich, September.

European Commission (EC). 2000. European Parliament and Council (2000) Directive 2000/60/EC of the European Parliament and of the Council of 23 October 2000 establishing a framework for Community action in the field of water policy.

Eigenberg, R.A., R.L. Korthals, and J.A. Nienaber. (1998). Geophysical electromagnetic survey methods applied to agricultural waste sites. J. Environ. Qual. 27, 215-219.

Fetter, C.W. (2001) Applied Hydeogeology . Fourth Ed. Prentice-Hall, New Jersey pp596.

Foppen, J.W.A., Schijven, J.F. (2006) Evaluation of data from the literature on the transport and survival of Escherischia coli and thermotolerant coliforms in aquifers under saturated conditions. Water Research, 40, 401-426.

Geological Survey of Ireland. GSI geological data download http://www.dcenr.gov.ie/Spatial+Data/Geological+Survey+of+Ireland/GSI+Spatial+Data+Downloa ds.htm Accessed (20 Oct 2014)

deGroot-Hedlin, C. and Constable, S. (1990). Occam's inversion to generate smooth, two-dimensional models form magnetotelluric data, Geophysics, 55, 1613-1624.

Hagedoorn, J.G. (1959). The plus-minus method of interpreting seismic refraction sections, Geophysical Prospecting, 7, 158-182.

Hatt, B.E., Fletcher, T.D., Walsh, C.J., Taylor, S. L. (2004) The influence of urban density and drainage infrastructure in concentrations and loads of pollutants in small streams. Environmental Management 34(1) 112-124.

Hoxley, G. Dudding, M. (1994) Groudwater contamination by septic tank effluent: Two case studies in Victoria Australia. Water Down Under: Groundwater/Surface Hydrology. Institution of Engineeers, Australia 1994 pp650.

Jenssen P. D. and Siegrist R. L. (1990). Technology assessment of wastewater treatment by soil infiltration systems. Water Sci. Technol. 22 (3/4), 83-92

Lee, B.D., Jenkinson, B.J., Doolittle, J.A., Taylor, R.S., and Tuttle, J.W. (2006). Electrical Conductivity of a Failed Septic System Soil Absorption Field, Vadose Zone Journal, 5, 757-763.

Littke, R., Klussmann, U., Krooss, B., \& Leythaeuser, D. (1991). Quantification of loss of calcite, pyrite, and organic matter due to weathering of Toarcian black shales and effects on kerogen and bitumen characteristics. Geochimica et Cosmochimica Acta, 55(11), 3369-3378.

Loke, M.H. and Barker, R.D. (1996). Rapid least-squares inversion of apparent resistivity pseudosections by a quasi-Newton method. Geophysical Prospecting, 44, 131-152 .

Loke, M.H. and Dahlin, T. (2002). A comparison of the Gauss-Newton and quasi-Newton methods in resistivity imaging inversion. Journal of Applied Geophysics, 49, 149-162.

Loke, M.H. (2004). Res2DInv ver. 3.54. Geoelectrical Imaging 2D and 3D. Instruction Manual. Geotomo Software.

Martínez-Pagán, P., Faz, A. and Aracil, E. (2009). The use of 2D electrical tomography to assess pollution in slurry ponds of the Murcia region, SE Spain, Near Surface Geophysics, 7(1), 49-61.

Martinho, E. and Almeida, F. (2006). 3D behaviour of contamination in landfill sites using 2D resistivity/IP imaging: case studies in Portugal, Environmental Geology, 49, 1071-1078.

McCarthy, V., Flynn, R., Orr, A., Rafferty, P, Minet, E., Meehan, R., Archbold, M. and Linnane, S. (2010). A field study assessing the impact of on-site wastewater treatment systems (OSWTS) on surface water in a Co. Monaghan catchment, Dundalk Institute of Technology (DKIT) Report.

McKerrow, W.S. (1981) The distribution of Lower Palaeozoic mudrocks in Britain. Quarterly Journal of Engineering Geology 14, 245-251.

Moe, H., Craig, M. and Daly, D. (2010). Poorly productive aquifers monitoring installations and conceptual understanding, Joint Environmental Protection Agency (EPA), CDM report, 42p.

Nitsche, J. (2014) Physical characterisation of groundwater flow systems of selected poorly productive bedrock aquifers in Ireland. PhD Thesis, The Queen's University of Belfast, 284 pages. 
O'Connor, P. Balding, B., Donohue, S., Gibson, P., , Hodgson, J., O'Connell, Y., Reid, G. and Staunton, R. Guidelines for near surface engineering \& environmental geophysical investigations in Ireland, Geophysical Association of Ireland, In Preparation.

Palmer, D. (1980). The generalized reciprocal method of seismic refraction interpretation. Society of Exploration Geophysicists, Tulsa, OK, $104 \mathrm{p}$.

Perozzi, L and Holliger, K. (2008). Detection and Characterization of Preferential Flow Paths in the Downstream Area of a Hazardous Landfill, Journal of Environmental and Engineering Geophysics, 13(4), 343-350.

Ranjan, R.S., and Karthigesu, T. (1995). Evaluation of an electromagnetic method for detecting lateral seepage around manure storage lagoons. ASAE Pap. no. 952440.

Robbins, N.S., (2002) Groundwater quality in Scotland: major ion chemistry of the key groundwater bodies. Science of the Total Envrionment 294(1) 41-56.

Rogers, R., McConnell, B., Cooper, M. (2015) Remapping the Moffat Shale Group using Tellus geophysics. Proc of $58^{\text {th }}$ IGRM 20-22 Feb 2015, Belfast, pp68.

Ryan, J. N., Elimelech, M., Ard, R. A., Harvey, R. W., \& Johnson, P. R. (1999). Bacteriophage PRD1 and silica colloid transport and recovery in an iron oxide-coated sand aquifer. Environmental science \& technology, 33(1), 63-73.

Santos, F.A.M., Mateus, A., Figueiras, J.and Gonçalves, M.A. (2006). Mapping groundwater contamination around a landfill facility using the VLF-EM method- A case study, Journal of Applied Geophysics, 60, 115-125.

Sasaki, Y. (1989). Two-dimensional joint inversion of magnetotelluric and dipole- dipole resistivity data. Geophysics, 54, 254- 262.

Sloss, L. L. (1963). Sequences in the cratonic interior of North America. Geological Society of America Bulletin, 74(2), 93-114.

Stevens, R.J., C.J. O'Bric, and O.T. Carton. (1995). Estimating nutrient content of animal slurries using electrical conductivity. J. Agric. Sci., 125,233-238.

Summerfield, M. A. (1991). Global geomorphology. Routledge.

Tesoriero, A. J., Liebscher, H., \& Cox, S. E. (2000). Mechanism and rate of denitrification in an agricultural watershed: Electron and mass balance along groundwater flow paths. Water Resources Research, 36(6), 1545-1559.

van Cuyk, S., Siegrist, R., Logan, A., Masson, S., Fischer, E. and Figueroa, L. (2001) Hydraulic and purification behaviours and their interactions during wastewater treatment in soil infiltrations systems, Water Resources, 35, 953-964.

Viraraghavan, T. (1976) Septic Tank Efficiency. Journal of Environmental Engineering Division ASCE 102(2) 505-508.

Withers, PJA, Jarvie, H.P. Stoate, C (2011) Quantifying the impact of septic tank systems on eutrophication risk in rural headwaters. Environment International 37(3) 644-653.

Wyrobek, S.M. (1956). Application of delay and intercept times in the interpretation of multi-layer refraction time distance curves. Geophysical Prospecting, 4(2), 112-130.

Yates, M.V., Yates, S.R. Wagner, J., and Gerba, C. P. (1987) Modeling virus survival and transport in the subsurface. Journal of Contaminant Hydrology 1, 329-345. 


\begin{tabular}{llll}
\hline Profile & $\begin{array}{l}\text { Array } \\
\text { Type }\end{array}$ & $\begin{array}{l}\text { Profile } \\
\text { Length } \\
(\mathrm{m})\end{array}$ & $\begin{array}{l}\text { Electrode } \\
\text { Spacing } \\
(\mathrm{m})\end{array}$ \\
\hline R 1 & Wenner $\alpha$ & 31 & 1 \\
R 2 & Wenner $\alpha$ & 15.5 & 0.5 \\
R 3 & Wenner $\alpha$ & 62 & 2 \\
R 4 & Wenner $\alpha$ & 62 & 2 \\
R 5 & Wenner $\alpha$ & 62 & 2 \\
R 6 & Wenner $\alpha$ & 52 & 2 \\
R 7 & Wenner $\alpha$ & 62 & 2 \\
R 8 & Wenner $\alpha$ & 23 & 1 \\
R 9 & Wenner $\alpha$ & 17.25 & 0.75 \\
R 10 & Wenner $\alpha$ & 23 & 1 \\
R 11 & Wenner $\alpha$ & 23 & 1 \\
\hline
\end{tabular}

Table 1: ERT data acquisition parameters used in profiles generated at the Drumaliss Test Site, Co. Monaghan.

\begin{tabular}{|c|c|c|c|}
\hline Profile & $\begin{array}{c}\text { Num. } \\
\text { Geophones }\end{array}$ & $\begin{array}{c}\text { Geophone } \\
\text { Spacing (m) }\end{array}$ & Source Locations \\
\hline S 1 & 24 & 1 & $\mathrm{G} 1+2 \mathrm{~m}(\mathrm{o}), \mathrm{G} 1, \mathrm{G} 6, \mathrm{G} 12, \mathrm{G} 18, \mathrm{G} 24, \mathrm{G} 24+10 \mathrm{~m}$ (o) \\
\hline S 2 & 24 & 0.75 & $\mathrm{G} 1+2 \mathrm{~m}(\mathrm{o}), \mathrm{G} 1, \mathrm{G} 6, \mathrm{G} 12, \mathrm{G} 18, \mathrm{G} 24, \mathrm{G} 24+10 \mathrm{~m}$ (0) \\
\hline S 3 & 24 & 2 & $\mathrm{G} 1+10 \mathrm{~m}(\mathrm{o}), \mathrm{G} 1, \mathrm{G} 6, \mathrm{G} 12, \mathrm{G} 18, \mathrm{G} 24, \mathrm{G} 24+10 \mathrm{~m}$ (0) \\
\hline S 4 & 24 & 1 & $\mathrm{G} 1+10 \mathrm{~m}(\mathrm{o}), \mathrm{G} 1, \mathrm{G} 6, \mathrm{G} 12, \mathrm{G} 18, \mathrm{G} 24, \mathrm{G} 24+10 \mathrm{~m}$ (0) \\
\hline S 5 & 24 & 1 & G1+4m (o), G1, G6, G12, G18, G24, G24+10m (o) \\
\hline
\end{tabular}

Table 2: Seismic data acquisition parameters. Note: (o) refers to seismic refraction offshots. 
$\begin{array}{llllll}\text { Borehole* }^{*} & \text { D4 } & \text { D6 } & \text { D7 } & \text { D8 } & \text { D9 }\end{array}$

Depth to Groundwater (mBGS)

\begin{tabular}{|l|c|c|c|c|c|}
\hline Sample size & 22 & 19 & 22 & 22 & 22 \\
\hline Minimum & 0.15 & 1.83 & 1.75 & 1.81 & 0.42 \\
\hline 25th Percentile & 0.1775 & 2.07 & 1.935 & 1.9725 & 0.57 \\
\hline Median & 0.2 & 2.25 & 2 & 2.125 & 0.59 \\
\hline 75th Percentile & 0.2175 & 2.425 & 2.0675 & 2.215 & 0.63 \\
\hline Maximum & 0.28 & 2.65 & 2.24 & 2.35 & 0.68 \\
\hline
\end{tabular}

Specific Electrical Conductivity (uS/cm)

\begin{tabular}{|l|c|c|c|c|c|}
\hline Sample size & 20 & 4 & 12 & 20 & 20 \\
\hline Minimum & 1189 & 225 & 126 & 147 & 222 \\
\hline 25th Percentile & 1650 & 230 & 233 & 216 & 369 \\
\hline Median & 1953 & 255 & 298 & 242 & 409 \\
\hline 75th Percentile & 2614 & 274 & 442 & 369 & 600 \\
\hline Maximum & 4601 & 302 & 787 & 713 & 1075 \\
\hline
\end{tabular}

Chloride (mg/L)

\begin{tabular}{|l|c|c|c|c|c|}
\hline Sample size & 18.0 & 5.0 & 13.0 & 18.0 & 18.0 \\
\hline Minimum & 95.0 & 12.4 & 10.3 & 10.0 & 10.9 \\
\hline 25th Percentile & 99.8 & 12.4 & 13.0 & 11.0 & 27.1 \\
\hline Median & 103.8 & 15.0 & 15.2 & 11.4 & 45.7 \\
\hline 75th Percentile & 106.7 & 15.4 & 18.0 & 12.7 & 59.3 \\
\hline Maximum & 128.1 & 16.3 & 20.1 & 26.6 & 69.0 \\
\hline
\end{tabular}

Total Coliforms -37 Deg C(MPN/100ml)

\begin{tabular}{|l|c|c|c|c|c|}
\hline Sample size & 18 & 4 & 16 & 19 & 19 \\
\hline Minimum & 172 & 36 & $<1$ & $<1$ & $<1$ \\
\hline 25th Percentile & 500 & 36 & 8 & $<1$ & 3 \\
\hline Median & $>2419$ & 518 & 29 & $<1$ & 91 \\
\hline 75th Percentile & $>2419$ & 785 & 1109 & 1 & 365 \\
\hline Maximum & 241960 & 1414 & $>2419$ & 210 & $>2419$ \\
\hline
\end{tabular}

\section{Ecoli}

(MPN/100ml)

\begin{tabular}{|l|c|c|c|c|c|}
\hline Sample size & 18 & 4 & 16 & 19 & 19 \\
\hline Minimum & $<1$ & 4 & $<1$ & $<1$ & $<1$ \\
\hline 25th Percentile & 18 & 4 & 3 & $<1$ & $<1$ \\
\hline Median & 27 & 28 & 9 & $<1$ & $<1$ \\
\hline 75th Percentile & 484 & 124 & 27 & $<1$ & 2 \\
\hline Maximum & 11190 & 397 & $>2419$ & 77 & 365 \\
\hline
\end{tabular}

Table 3: Summary statistics for depth of groundwater and water quality parameters for groundwater samples collected from the Drumaliss Test Site, Co. Monaghan, Ireland over a 12 month monitoring period. Differences in sample numbers from each monitoring point reflect their ability to provide 
sufficient volumes of water for analyses over the monitoring period. Samples collected from Piezometer D1 displayed evidence of sewage contamination. Background Chloride concentrations were estimated from lower quartile levels in samples collected from piezometers D4, D6 and D8 as approximately $12 \mathrm{mg} / \mathrm{l}$.

\begin{tabular}{|c|c|c|c|c|}
\hline $\begin{array}{c}\text { Piezometer } \\
\text { ID }\end{array}$ & $\mathrm{K}(\mathrm{cm} / \mathrm{s})$ & $\begin{array}{c}\text { Minimum } \\
(\mathrm{cm} / \mathrm{s})\end{array}$ & $\begin{array}{c}\text { Geometric } \\
\text { Mean }(\mathrm{cm} / \mathrm{s})\end{array}$ & $\begin{array}{c}\text { Maximum } \\
(\mathrm{cm} / \mathrm{s})\end{array}$ \\
\hline $\mathrm{D} 1$ & $1.12 \times 10^{-4}$ & \multirow{5}{*}{$2.88 \times 10^{-6}$} & \multirow{5}{*}{$8.75 \times 10^{-5}$} & \multirow{5}{*}{$1.28 \times 10^{-3}$} \\
\hline $\mathrm{D} 4$ & $1.22 \times 10^{-4}$ & & & \\
\hline D7 & $2.88 \times 10^{-6}$ & & & \\
\hline D8 & $1.02 \times 10^{-4}$ & & & \\
\hline D9 & $1.28 \times 10^{-3}$ & & & \\
\hline
\end{tabular}

Table 4: Summary of hydraulic conductivity values calculated for deposits surrounding screened intervals of permanent monitoring wells at the Drumaliss Test Site, Co. Monaghan, Ireland. The three columns on the right hand side of the table summarise the results of measurements made at individual monitoring points. 


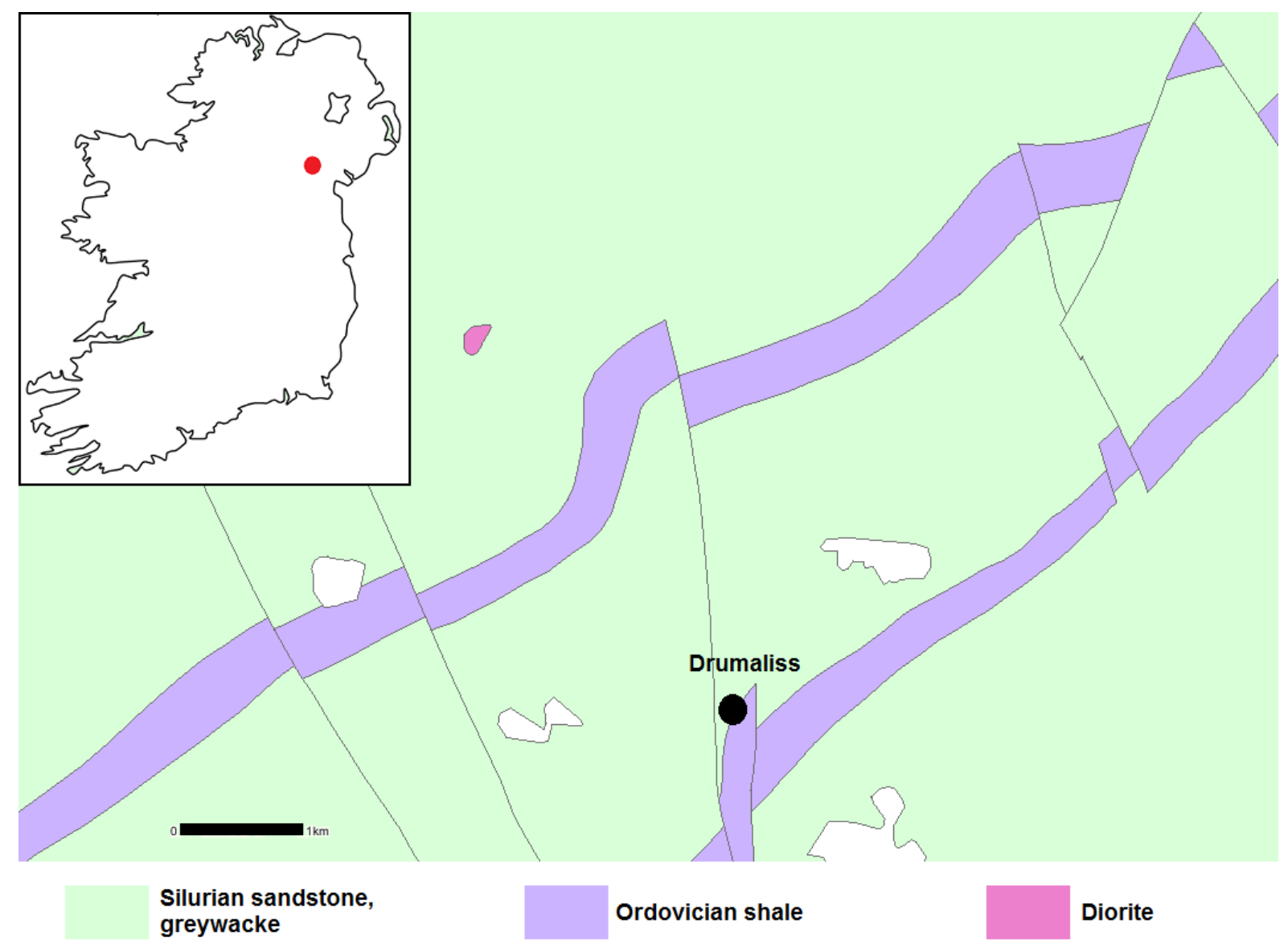

Figure 1: Geological map of the area, indicating the location of the Drumaliss Test Site (Source: Geological Survey of Ireland). Inset: Location of the test sites within Ireland. Note: White polygons refer to surface water. 


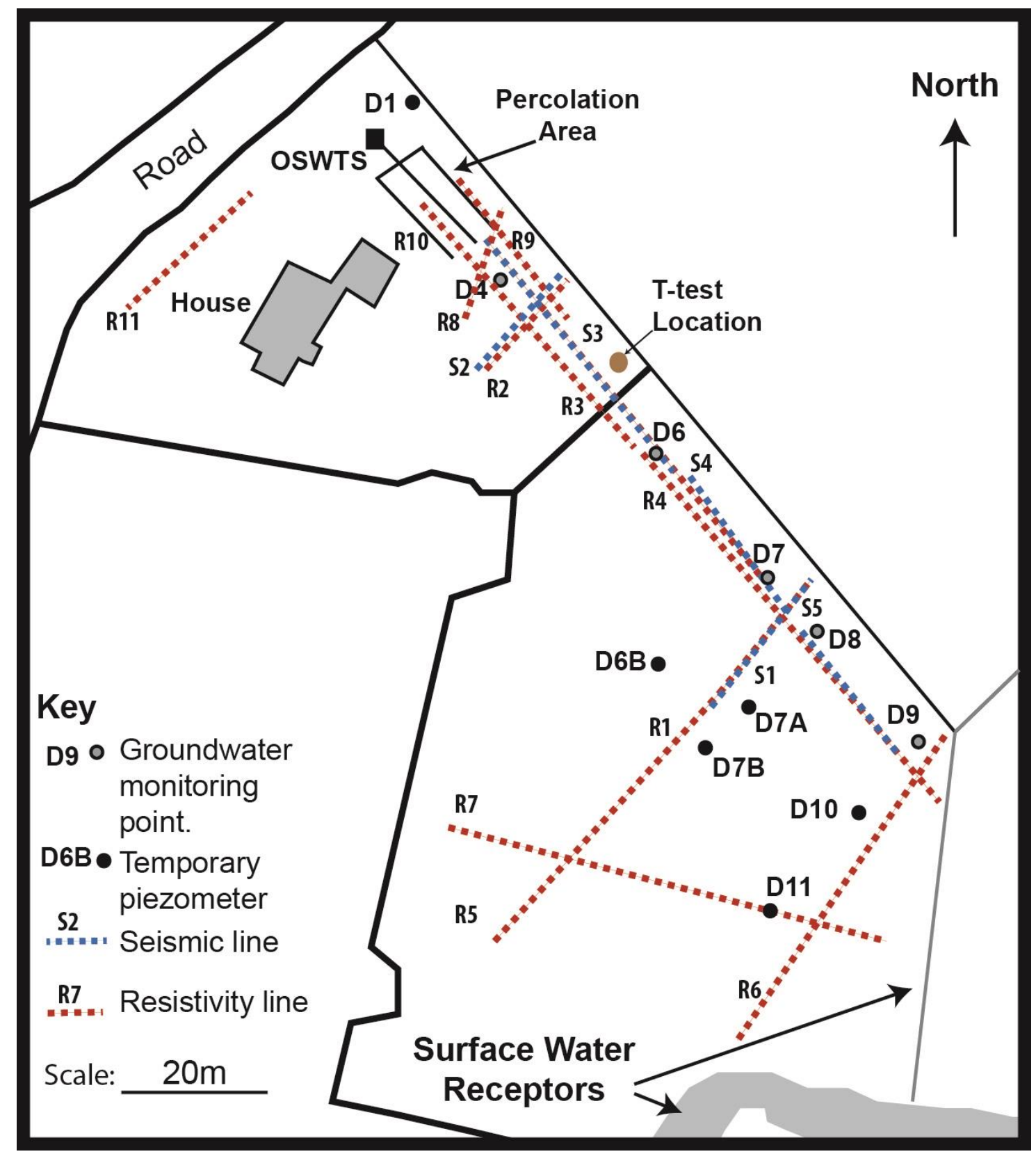

Figure 2: Drumaliss site map, showing locations of the wastewater treatment and percolation area, piezometers (black circles), ERT profiles (red lines) and seismic refraction profiles (blue lines). 


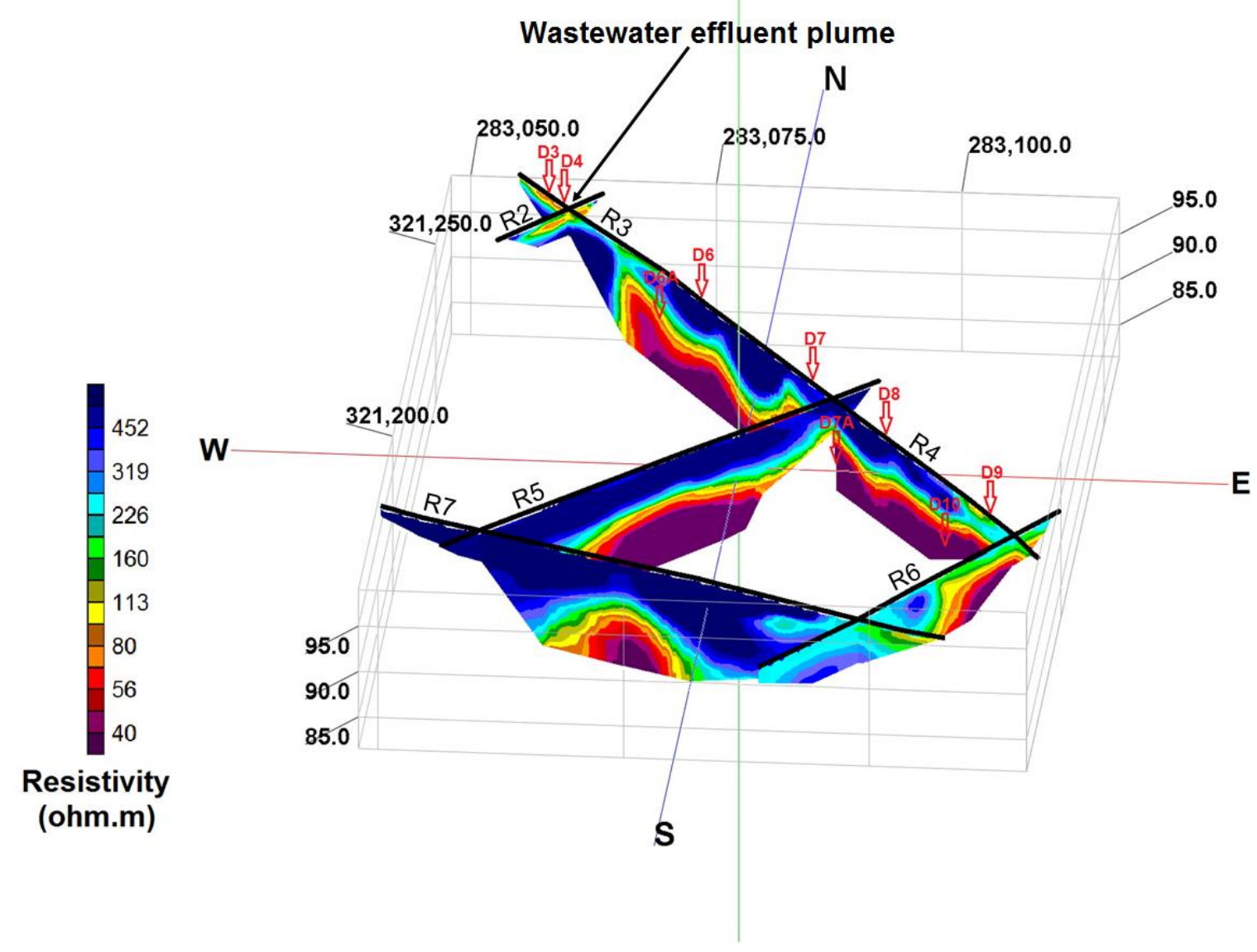

Figure 3: Fence diagram of ERT profiles R1-R7, with piezometer locations indicated by red arrows. Note: High resolution ERT profiles close to the treatment system are illustrated separately in Figure 4 for clarity. 


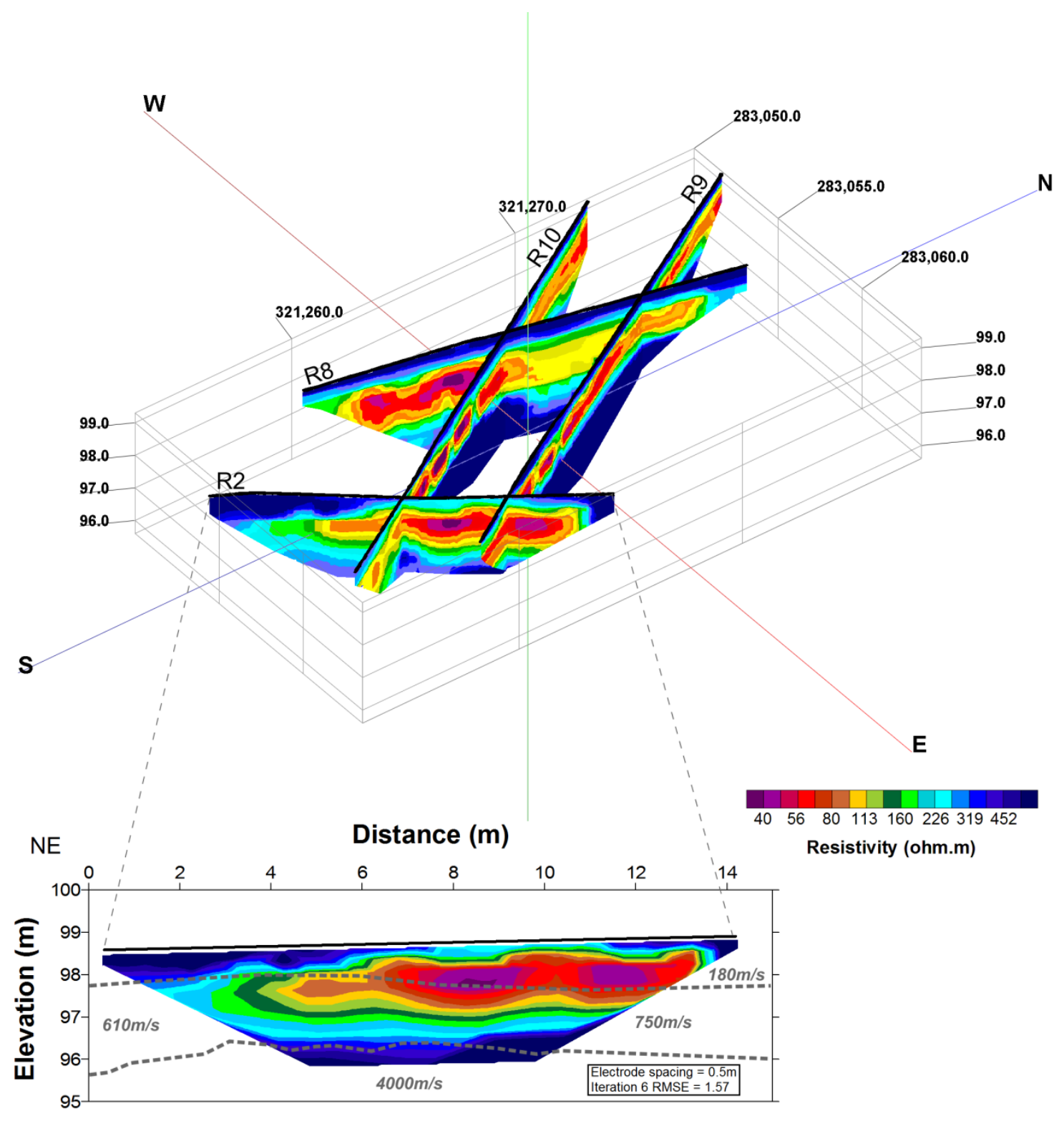

Figure 4: Fence diagram of high resolution ERT profiles located close to the wastewater treatment system. Inset: Seismic refraction profile S2 overlain on inverted ERT profile R2 for joint interpretation. 


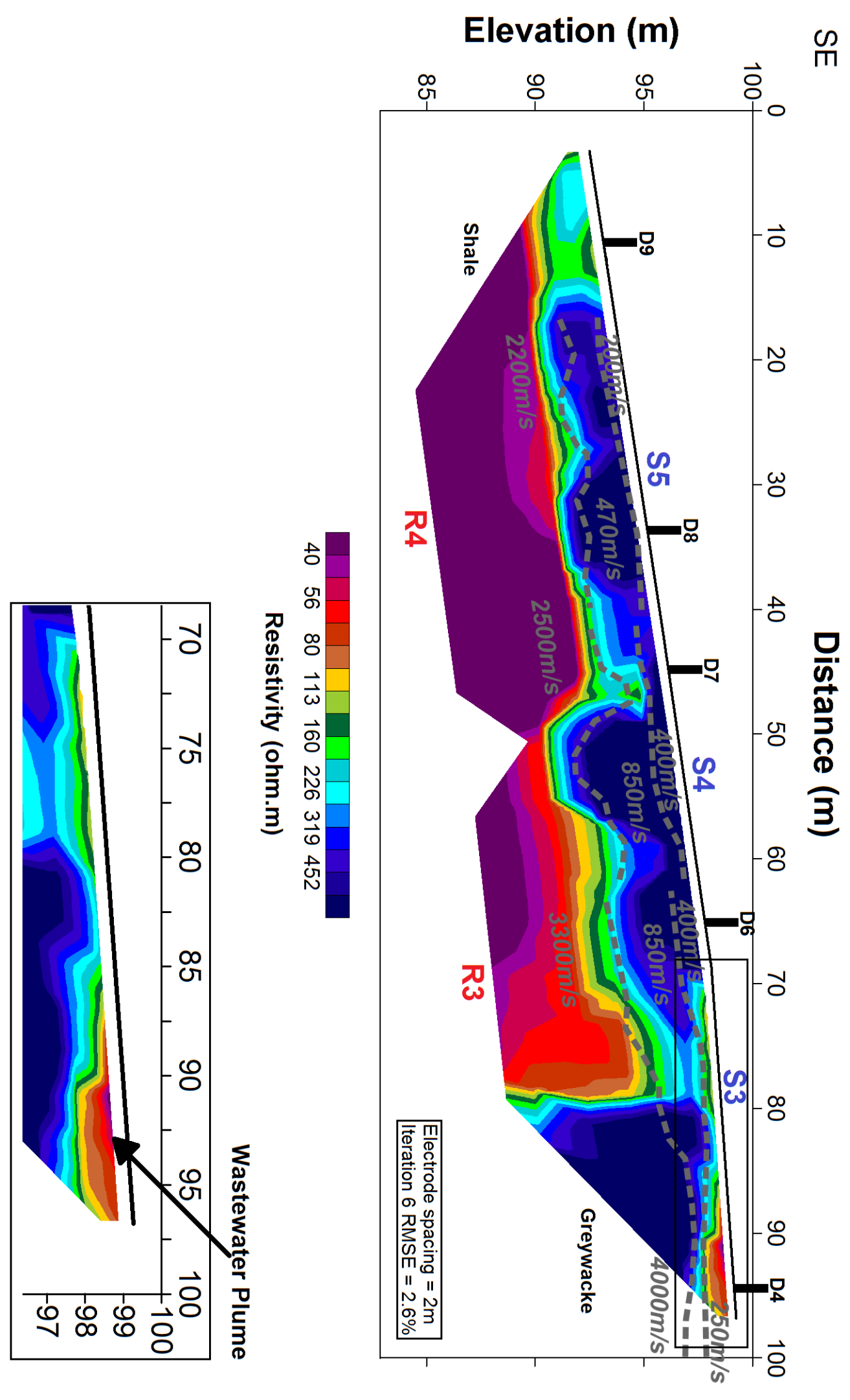

Figure 5: Seismic refraction profiles S3, S4 and S5 overlain on inverted ERT profiles R3 and R4 for joint interpretation. Boxed: Magnified image to display extent of effluent plume. 


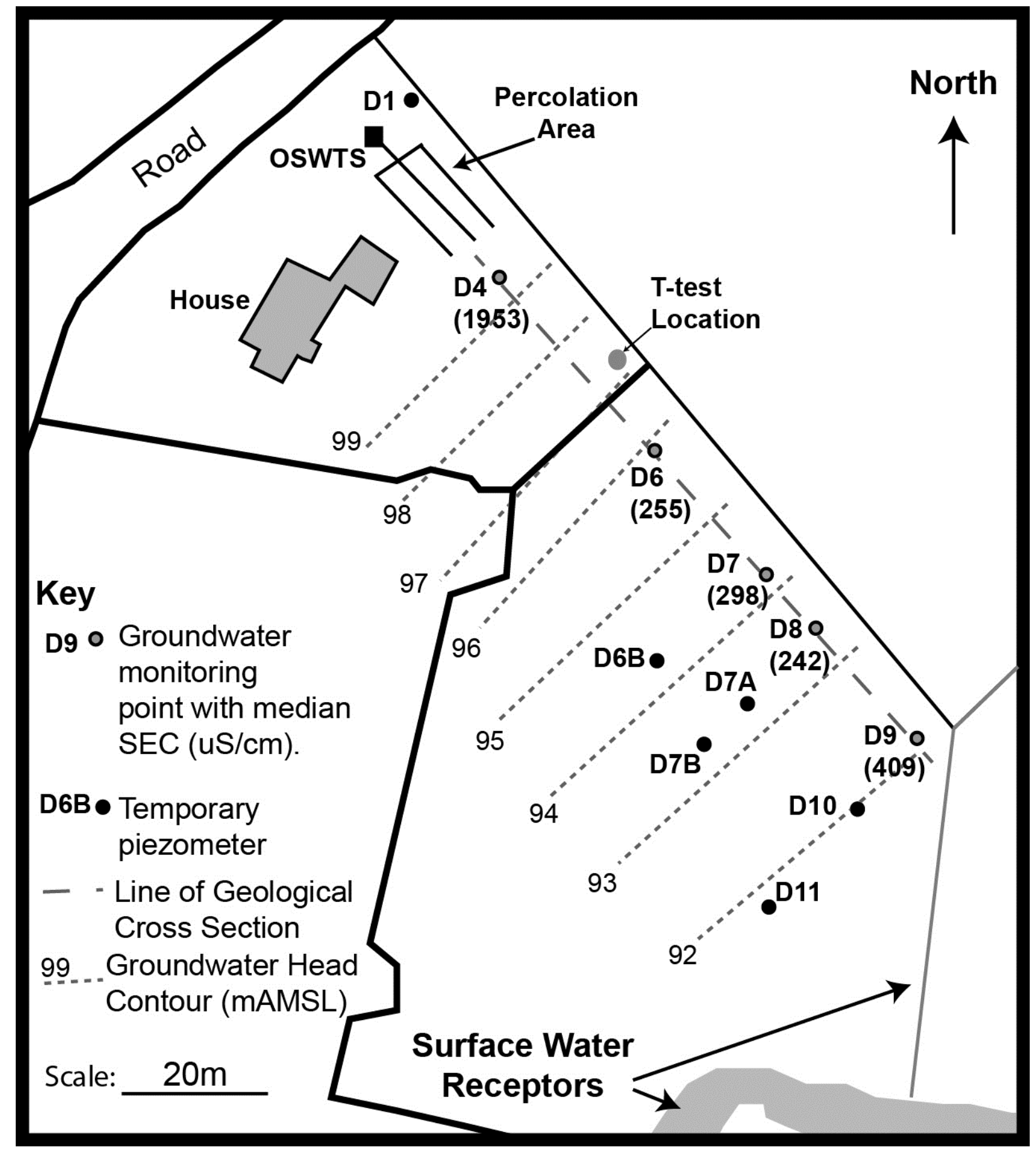

Figure 6: Map of the Drumaliss site, showing the median specific electrical conductance (SEC) concentration measured at the groundwater monitoring points, groundwater head contours (for July 2010) and the location of the geological cross section illustrated in Figure 7. Median SEC concentrations were calculated from data collected over a 12 month sampling period. Water levels observed during July 2010 fall within the range observed during the summer of the 2007-2008 monitoring period. 


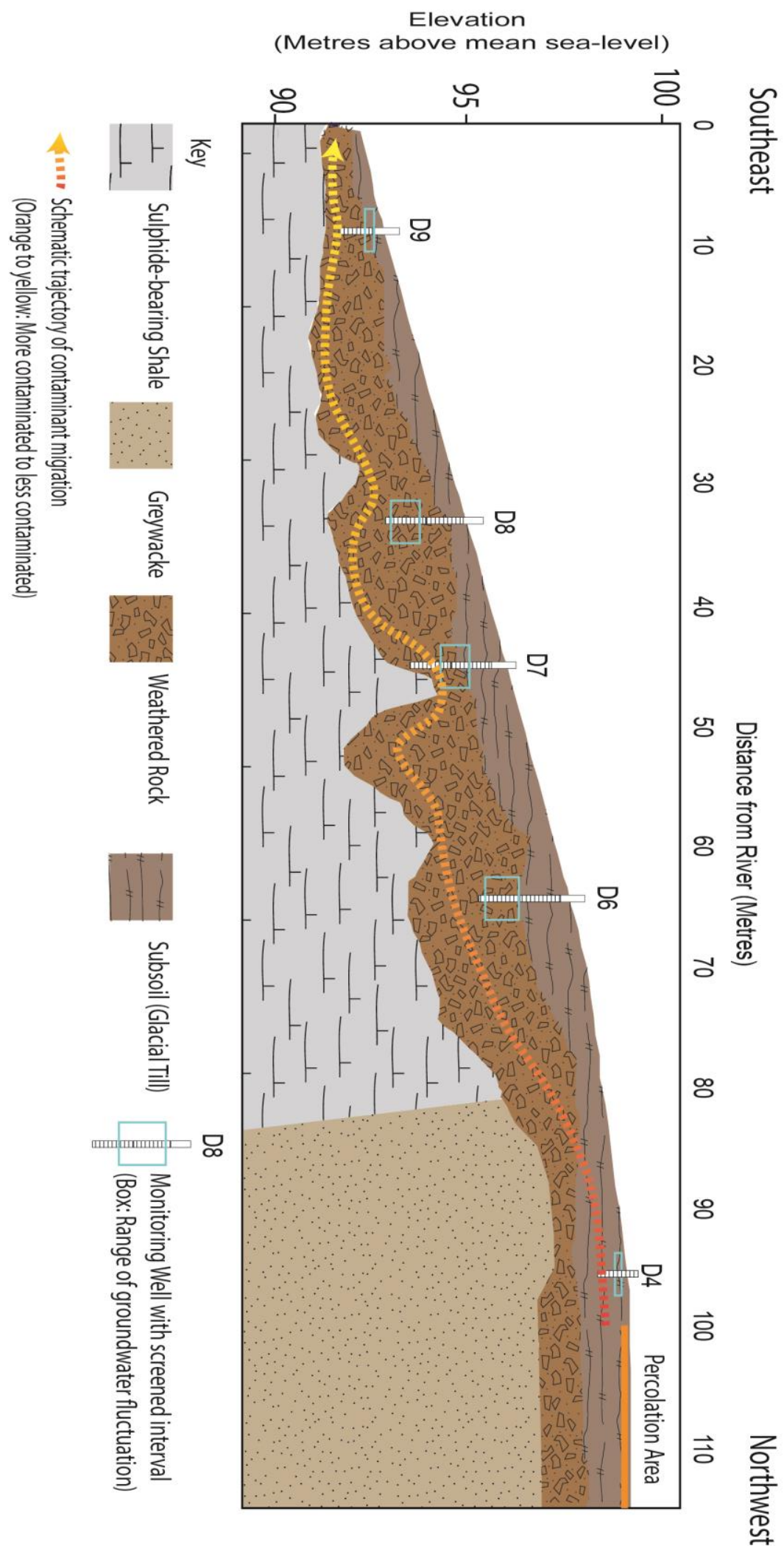

Figure 7: Schematic hydrogeological cross section of Drumaliss Test Site, Co. Monaghan, Ireland. The contaminant migration trajectory illustrates the path followed by the contaminant plume. Wells not intersecting this line will contain OSWTS-derived contaminants, but at lower levels than they would have had they intersected the line.

Page $\mid 27$ 